\title{
Radiation Biology, Electromagnetic Fields
}

National Cancer Institute

\section{Source}

National Cancer Institute. Radiation Biology, Electromagnetic Fields. NCI Thesaurus.

Code $C 18978$.

The study of the mechanisms and biological effects of electromagnetic fields. 